\title{
Thermal Treatment of Tender Coconut Water - Enzyme Inactivation and Biochemical Characterization
}

\author{
Shivashankar Sanganamoni1 ${ }^{*}$, S. Mallesh ${ }^{2}$, K. Vandana $^{1}$ and P. Srinivasa Rao ${ }^{1}$ \\ ${ }^{1}$ Agricultural and Food Engineering Department, IIT Kharagpur - 721 302, India \\ ${ }^{2}$ GB Pant University of Agriculture and Technology - Pantnagar - 263 145, India \\ *Corresponding author
}

\section{A B S T R A C T}

The effect of thermal treatment on enzymes (viz. Polyphenol oxidase and Peroxidase) and nutritional properties (viz. Ascorbic acid, Antioxidant activity and Total phenolic content)

\section{Keywords}

Tender coconut water, Thermal treatment, PPO, POD, Total phenols.

Article Info

Accepted:

26 April 2017

Available Online:

10 May 2017 of tender coconut water (Cocos nucifera) were studied during this research work. The process conditions for thermal treatment were temperature $\left(80,85,90,95{ }^{\circ} \mathrm{C}\right)$ and treatment time $(2.5,5,7.5,10 \mathrm{~min})$. The results obtained from this study showed that the thermal treatment conditions had significant effect on ascorbic acid, total phenols, antioxidant activity, PPO and POD. Further, inactivation kinetics parameters (viz. D value and $\mathrm{Z}$ value) were calculated for PPO and POD at different temperatures. The complete inactivation of POD achieved after thermal processing at $95{ }^{\circ} \mathrm{C}$ for 5 minutes, though the experiment was continued up to 10 minutes because at this stage the PPO didn't inactive completely. These results evident that the PPO was more heat resistant than POD in thermal treatment. Further, the results were compared with enzyme activity and nutritional properties of tender coconut water after UV-C treatment. From the results the study was conclude that, although the thermal treatment was better processing option pertaining to enzyme inactivation, but ultraviolet treatment was found superior based on retention of nutritional attributes.

\section{Introduction}

Coconut water widely consumed as a beverage usually comes from immature coconut fruit which is at a tender stage and referred as tender coconut water. Coconut drink is gaining popularity in the beverage industry due to its high nutritional value and some potential therapeutic properties.

The tender coconut water is considered as a natural health drink due to its unique characteristics (Debmandal et al., 2011). Its sugar content and mineral composition makes it an ideal rehydrating and refreshing drink
(Campbell et al., 2000). This natural drink is believed to be useful in preventing and relieving many health problems, including dehydration, constipation, digestive problems, fatigue, heatstroke, diarrhea, kidney stones and urinary tract infections (Campbell et al., 2000).

Market for tender coconut water is increasing considerably due to its medicinal, nutritional and sensory properties. Further market for processed bottled tender coconut water also increasing to reduce transport cost and easily 
available in all locations throughout a year. However, there is a challenge for developing process to ensure that the product is available with safety and high nutritional and sensory quality. Generally, the tender coconut water present inside the fruit is shelf sterile and stable for few days (Yong et al., 2009), but shelf life of extracted tender coconut water is very less. The spoilage of extracted TCW mainly due to the presence of enzymes, belonging to oxidase family (Polyphenol oxidase and Peroxidase), that in contact with atmospheric oxygen. The oxidative enzymes have high thermal resistance and their activity leads to yellow, brown or even pink colouring during storage, even under refrigeration.

Polyphenol oxidase (PPO) and Peroxidase (POD) are widely detected in many fruits and vegetables and are closely linked to enzymatic color changes with consequently loose on sensorial properties (Campos et al., 1996). According to some food technologists, Polyphenol oxidase is indirectly responsible for fruit and vegetables enzymatic browning, it catalyzes two types of oxidative reactions. Such as hydroxylation of monophenols to odiphenols, and the oxidation of this last one colorless compound to highly colored oquinones.

Presently thermal treatment is most commonly applied for inactivating enzymes in coconut water. Thermal treatment required less maintenance and low energy consumption. By considering the facts, the present experiment was aimed to study the effect of thermal treatment on bioactive components and enzyme activity kinetics.

\section{Materials and Methods}

\section{Procurement of Tender Coconut Water (TCW)}

6-8 months matured tender coconut fruits of approximately same size contained coconut flesh (jelly like) less than $2 \mathrm{~mm}$ and without any visible damage on outside were purchased from local market at IIT Kharagpur. Surface of coconut husk was properly cleaned with distilled water followed by $1 \%$ sodium hypochlorite sanitize solution (Walter et al., 2009). After, the coconuts were placed in laminar flow UV light chamber for 30 min to make coconuts free from surface contamination.

Tender coconut water was manually extracted from coconut fruit using free washed and sanitized sharp stainless steel, and filtered through muslin cloth. The filtered TCW obtained from several fruits (4-5 coconut fruits having same maturity level) was mixed in a glass beaker. The mixed TCW was filled and packed in LDPE (low density polyethylene) pouches and immediately stored at -18 C before use. Whole TCW extracted from fruit was processed on the same day of extraction.

\section{Chemicals and reagents}

All the chemicals and reagents used in the study were analytical grade and procured from Merck, India and Sigma-Aldrich, Germany.

\section{Thermal treatment of tender coconut water}

Thermal treatments were performed in a temperature controlled $\left( \pm 0.5{ }^{\circ} \mathrm{C}\right)$ water bath Ultrasonic cleaner-Memory Quick, Takashi: UD80 $\mathrm{SH}-3 \mathrm{~L}$ ) at $80,85,90,95{ }^{\circ} \mathrm{C}$ for $2.5,5$, $7.5,10 \mathrm{~min}$. Approximately $50 \mathrm{ml}$ of coconut water was filled and packed in $\mathrm{EVOH}$ (Ethylene vinyl alcohol copolymer) packing film. The packets were placed in a water bath and the count down time began when center of the sample reached the target temperature. Physicochemical, nutritional properties and enzyme activity were calculated after thermal treatment of TCW. 


\section{Experimental design}

Full factorial design with 3 replications was followed throughout the experiment. The independent variables viz. Treatment time $(\mathrm{t}-$ 2.5, 5, 7.5, $10 \mathrm{~min}$ ) and Temperature (T- 80, $85,90,95{ }^{\circ} \mathrm{C}$ ) were selected with four levels of each of independent variables and their combinations had been investigated for each attribute. After each experiment, Relative activity of PPO, POD and nutritional properties (viz. Ascorbic acid, Total phenolic content and Antioxidant activity) were analyzed to know the effect of treatment on its.

\section{Measurement of bioactive components of tender coconut water}

\section{Measurement of ascorbic acid (AA)}

Ascorbic acid (AA) content of TCW was determined by spectrophotometric method based on its ability to decolorize 2, 6dichlorophenol-indophenol dye solution proposed by Ranganna (1991). Briefly, take 1 $\mathrm{mL}$ of sample and make up to $5 \mathrm{~mL}$ with $2 \%$ Metaphosphoric acid $\left(\mathrm{HPO}_{3}\right)$ solution. Then mix with $10 \mathrm{~mL}$ dye solution and measure the absorbance at $518 \mathrm{~nm}$ using UV-visible spectrophotometer against blank (contains 5 $\mathrm{ml} 2 \% \quad \mathrm{HPO}_{3}+10 \mathrm{~mL}$ distilled water). Interference was avoided by rapid determination and the corresponding AA content was obtained from a standard curve drawn for pure L-ascorbic acid (SigmaAldrich) solution which varied within 0.2 to 1 $\mathrm{g} \cdot \mathrm{L}^{-1}$

Standard AA conc. $\left(\mathrm{mg} \cdot \mathrm{mL}^{-1}\right)=0.783 \times$ (absorbance) (1)

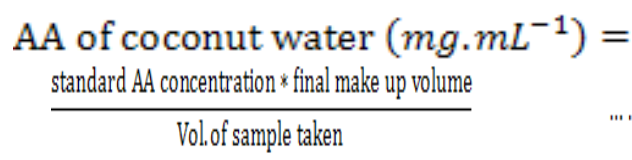

Total phenols by Folin-Ciocalteu reagent (FCR) assay

The methanolic extract of coconut water was used for analysis of total phenols and antioxidant capacity. It was prepared by shaking a solution of $5 \mathrm{~mL}$ coconut water with $25 \mathrm{~mL} 80 \%$ methanol in distilled water for $3 \mathrm{~h}$ at ambient temperature $\left(27 \pm 1^{\circ} \mathrm{C}\right)$.

Total phenol content was determined using the Folin-Ciocalteu reagent (FCR) assay according to the method of Singleton et al., (1999) with slight modifications as described by Wijngaard and Brunton (2010). The blue color was developed using a Folin-Ciocalteu reagent (FCR) in an alkaline medium (20\% sodium carbonate) over 90 minutes and its absorbance was measured at $750 \mathrm{~nm}$ in a UVvisible spectrophotometer (Model: UV1700; Make: Shimadzu, Japan). Gallic acid was taken as standard for the phenolic and total phenolic content was expressed in Gallic acid equivalent.

Standard Phenolic conc. (GAE in mg. $\left.\mathrm{mL}^{-1}\right)=$ $0.2437 \times$ (absorbance)

phenolic concentration of coconut water (GAE in $\left.m g \cdot m L^{-1}\right)=$ standard phenolic concentration * volume made up

vol, of methanolic extract taken for estimation * Vol of sample taken extraction $\ldots . .(4)$

\section{Antioxidant activity by 2, 2-diphenyl-1- picrylhydrazyl (DPPH) assay}

The antioxidant activity of the extract was measured in terms of its DPPH radical scavenging ability. It represents the ability of the food product to resist oxidation. The advantage of the DPPH method is that free radicals are allowed to react with the whole sample and the relatively longer time given in the method allows the free radical to react slowly even with weak antioxidants (Kedare and Singh, 2011). Methanolic extract of coconut water was used for the analysis of 
DPPH free radical scavenging activity and it was prepared as described for total phenol content. The DPPH assay was carried out according to the procedure of Goupy et al., (1999) with slight modifications as described by Wijngaard and Brunton (2010). The change in color of the DPPH solution from purple to yellow, resulting from the addition of different quantities of methanolic extract of coconut water or gallic acid (GA) standard (20 to $200 \mu \mathrm{L}$ ) was measured at $517 \mathrm{~nm}$ after allowing the solution to stand in the dark for $30 \mathrm{~min}$. The decrease in absorbance of DPPH after $30 \mathrm{~min}$ was calculated and expressed as mg of GA equivalents antioxidant capacity (GAEAC) per $100 \mathrm{~mL}$ of the sample using the formula given in Eq. (3.9)

GAEAC $=\frac{\Delta A b s_{\text {sample }}}{\Delta A b s_{G A}} * C_{G A} *\left(\frac{V}{W}\right) * 100$

Where,

$\Delta \mathrm{Abs}_{\text {sample }}$ is the change of absorbance after addition of coconut water extract

$\mathrm{C}_{\mathrm{GA}}$ is the concentration of $\mathrm{GA}$ standard solution $(0.02 \mathrm{mg} / \mathrm{mL})$;

$\Delta \mathrm{Abs}_{\mathrm{GA}}$ is the change of absorbance obtained from a calibration curve when the same volume GA standard solution as that of coconut water extract was added;

$\mathrm{V}$ is the final make up volume of extract; and $\mathrm{W}$ is the volume of sample used for extraction

\section{Enzyme activity measurement}

\section{Assay of polyphenol oxidase (PPO)}

Polyphenol oxidase (PPO) was determined using Pyrocatechol solution as phenol substrate proposed by Tan et al., (2014) with slight modifications. Briefly $5.5 \mathrm{ml}$ of $0.2 \mathrm{M}$ Sodium phosphate buffer of $\mathrm{pH} 6$ and $1.5 \mathrm{ml}$ of $0.2 \mathrm{M}$ pyrocatechol were added into a test tube. The test tube was then immersed in a control temperature water bath at $25^{\circ} \mathrm{C}$ for 2 min for thermal stabilization. Then add $2 \mathrm{ml}$ of coconut water mix properly and measure the change in absorbance at $420 \mathrm{~nm}$ using UV1700 UV Visible spectrophotometer with respect to the blank solution consist of $7.5 \mathrm{ml}$ buffer and $1.5 \mathrm{ml} 0.2 \mathrm{M}$ pyrocatechol.

\section{Assay of peroxidase (POD)}

Peroxidase (POD) was Determined according to the method proposed by Augusto et al., (2015) with slight modifications. 5\% (w/v) pyrogallol solution used as phenol substrate. In each assay $0.32 \mathrm{ml}$ of $5 \%$ pyrogallol solution, $2.36 \mathrm{ml}$ buffer and $0.16 \mathrm{ml}$ coconut water were mixed in a cuvette. Then $0.16 \mathrm{ml}$ of $0.5 \% \mathrm{H}_{2} \mathrm{O}_{2}$ added to this mixture (reaction will start after adding $\mathrm{H}_{2} \mathrm{O}_{2}$ ). The changes in absorbance was measured at $420 \mathrm{~nm}$ with respect to the blank solution contained 0.32 $\mathrm{ml} 5 \%$ pyrogallol, $2.52 \mathrm{ml}$ buffer and $0.16 \mathrm{ml}$ $0.5 \% \mathrm{H}_{2} \mathrm{O}_{2}$.

\section{Measurement of protein concentration}

For the estimation of protein concentration in the crude enzyme extract Bradford's Method was followed (Sadasivam and Manickam, 2011). Bradford's reagent was prepared by dissolving $100 \mathrm{mg}$ of Coomassie brilliant blue-G250 in $50 \mathrm{~mL} 95 \%$ ethanol and $100 \mathrm{~mL}$ concentrated orthophosphoric acid. The volume made upto $200 \mathrm{~mL}$ with distilled water. It can be diluted 4 times before use. 0.1 $\mathrm{mL}$ of enzyme extract was taken and $5 \mathrm{~mL}$ of Bradford's reagent was added. The absorbance values in a UV-Visible spectrophotometer against the blank (without sample extract) at $595 \mathrm{~nm}$ were recorded.

\section{Enzyme activity calculation}

For both the enzymes, the absorbance was measured at every $10 \mathrm{sec}$ interval for $15 \mathrm{~min}$. then slope of the absorbance curve drawn 
against time will gives the enzyme activity of coconut water. The enzyme activity was expressed in U.ml ${ }^{-1} \mathrm{~min}^{-1}$ ( $\mu \mathrm{g}$ of protein $)^{-1}$. The relative activity $\left(\mathrm{A}_{\text {rel }}\right)$ can be calculated by using equation 3.11 .

$\mathrm{Y}=\frac{A i \mathrm{x} P_{0}}{P_{i} x A 0}$

Where, $A_{o}$ and $A_{i}$ represent the slope of OD vs time curve in the untreated sample and sample, respectively; Pi represents the relative absorbance differences with respect to blank got from Bradford analysis for enzyme concentration in the extract in sample and Po represents the same as previous but for untreated sample. Slope was taken for every measurement in which correlation coefficient $\left(\mathrm{R}^{2}\right)$ is greater than 0.95 and it was done in Microsoft Excel 2013 software along with a precision up to four decimal places.

\section{Inactivation kinetics of PPO and POD}

Determination of PPO and POD enzymatic activities were carried. The calculated log $\left(\mathrm{A}_{\mathrm{i}} / \mathrm{A}_{0}\right)$ was plotted against holding time for all the three heating temperatures in order to obtain the $\mathrm{D}$ value using the following equation Tan et al., (2014).

Slope $=\frac{-1}{D}$

Where

$\mathrm{D}$ value is the time in seconds required to deactivate $1 \log$ cycle $(90 \%)$ of target enzyme or microorganism population under isothermal conditions.

Based on the $\mathrm{D}$ values obtained, $\log \mathrm{D}$ value was plotted against heating temperature in order to obtain the $\mathrm{z}$ value using the following equation

Slope $=\frac{-1}{z}$
Where

$\mathrm{Z}$ value is the temperature increase that reduces D-value by a factor of $10(90 \%)$.

\section{Data analysis}

Analysis of variance (ANOVA) test was conducted using Design expert version 7.0.0 software (State-Ease Inc., Minneapolis, USA) to evaluate the significance (at 95\% confidence level) of the effect of independent variables and their interactions on the responses.

A full factorial design was used to estimate the effect of independent variables (Treatment time and Temperature) on responses (PPO, POD, Ascorbic acid, Total phenolic content and Antioxidant activity).

\section{Optimization of process parameters}

RSM was applied to the experimental data using Design expert version 7.0.0 software (State-Ease Inc., Minneapolis, USA). The critical responses were screened out based on the effect and importance of responses. The optimization was targeted for maximum inactivation of PPO, POD and minimal changes in nutritional properties of TCW.

\section{Results and Discussion}

\section{Compositions of raw tender coconut water}

The nutritional properties and enzyme activity of TCW were analyzed before treatment. The compositions of TCW varied from fruit to fruit depending upon variety and maturity of fruit (Jackson et al., 2004 and Tan et al., 2014). Although there was important initial difference exist in physicochemical properties of TCW between different verities of fruit. But for comparison these parameters kept as constant for whole experiment. The 
compositions of fresh TCW were measured and presented in table 1 .

\section{Effect of thermal treatment on bioactive components of tender coconut water}

\section{Effect on ascorbic acid (AA)}

The $\%$ loss in ascorbic acid content in TCW after thermal treatment at different conditions with respect to control (unprocessed tender coconut water) was presented in figure 1 .

Ascorbic acid is a heat-sensitive bioactive compound that plays a vital role in human health and can act as an antioxidant.

The AA content of TCW was found to be in the range of 2.7 to $3.1 \mathrm{mg} / 100 \mathrm{~mL}$. The obtained values of AA are found to be slightly higher than the values reported by molecules et al., 2009.

The slight variation in AA might be due to the maturity and variety of TCW (Jackson et al., 2004). From ANOVA data it was showing that the thermal treatment conditions had significant $(p<0.0001)$ effect on ascorbic acid content in TCW. The results show that the loss of A.A increases with treatment time in thermal treatment.

The maximum loss of A.A in thermal treatment was found to be $14.6 \%$. Heating affects the degradation of ascorbic acid in an aerobic pathway due to its heat-sensitive characteristic in the presence of oxygen. In addition to this, the depletion of ascorbic acid may be due to the formation of free hydroxyl radicals by photochemical reaction, related to oxidative processes. The similar results were reported by Goh et al., (2012).

The loss of A.A is increased with temperature in thermal treatment.

\section{Effect on total phenolic content (TPC)}

The total phenolic content values of thermal processed TCW at different treatment conditions were presented in figure 2 .

Phenolic compounds are beneficial compounds mainly found in fruits and vegetables. They have been implicated in the reduction of degenerative diseases in human beings primarily because of their antioxidant potential. The TPC of coconut water was found to be in the range of 6.2 to $7.6 \mathrm{mg}$ of GAE/L. The obtained values of TPC were found to be slightly higher than the values reported by Tan et al., (2014). The slight variation in TPC might be due to the maturity and variety of TCW (Jackson et al., 2004). From ANOVA data it was showing that the thermal treatment conditions had significant $(\mathrm{p}<0.0001)$ effect on total phenolic content in TCW. The TPC of TCW was decreased after thermal treatment. The reason for such type of changes attributed to increase in temperature may destruct the phenolic compounds initial present in coconut water.

\section{Effect on antioxidant capacity}

The GAE Antioxidant capacity of coconut water values after thermal treatment at different conditions were presented in figure 3. The GAE Antioxidant capacity of coconut water was found to be in the range of 0.75 to $0.82 \mathrm{mg}$ of GAEAA/L.

From ANOVA data it was showing that the thermal treatment conditions had significant effect on Antioxidant activity of TCW. The antioxidant activity was decreased with increasing temperature and treatment time. The reason for such type of changes attributed to increase in temperature may destruct the phenolic compounds initial present in coconut water. 
Effect of UV light treatment on enzyme activity of tender coconut water

\section{Effect on polyphenol oxidase (PPO)}

The relative activity of PPO (with respect to control) of thermal processed TCW at different conditions was presented in figure 4 .

Generally, Polyphenol oxidases (PPO) are copper containing oxidoreductases that catalyze the hydroxylation and oxidation of phenolic compounds in the presence of molecular oxygen. The PPO activity of TCW was found to be in the range of $0.58-0.62$
$\left(\mathrm{U} \cdot \mathrm{mL}^{-1} \cdot \mathrm{min}^{-10} \mathrm{Brix}{ }^{-1}\right)$. The obtained values of PPO were found to be within the reported range in the literature (Tan et al., 2014). From ANOVA data it was showing that the thermal treatment conditions had significant $(\mathrm{p}<0.0001)$ effect on PPO activity in TCW. The relative activity of PPO was decreased with increasing the temperature and treatment time in TCW. The same trend was reported by Falguera et al., (2011) conducted on apple juice. The reason for such type of changes mainly attributed to increase in temperature may affect the biosynthesis process which results in protein degradation in tender coconut water.

Table.1 Enzyme activity and biochemical characterization of tender coconut water

\begin{tabular}{ll}
\hline Parameters & Value \\
\hline Ascorbic acid & $2.7 \pm 0.25$ \\
Total phenolic content (mg of GAE/ L) & $63.1 \pm 0.4$ \\
Antioxidant activity $(\mathrm{mg}$ of GAEAC/ L) & $8.1 \pm 0.5$ \\
PPO $\left(\mathrm{U} \cdot \mathrm{mL}^{-1} \cdot \mathrm{min}^{-10} \mathrm{Brix}^{-1}\right)$ & $0.59 \pm 0.015$ \\
POD $\left(\mathrm{U} \cdot \mathrm{mL}^{-1} \cdot \mathrm{min}^{-10} \mathrm{Brix}^{-1}\right)$ & $0.06 \pm 0.024$ \\
\hline
\end{tabular}

Note: Values reported as mean \pm standard deviation $(\mathrm{N}=12)$.

Table.2 Inactivation parameters for PPO and POD of tender coconut water

\begin{tabular}{llcl}
\hline & & PPO & POD \\
\hline \multirow{2}{*}{$80^{\circ} \mathrm{C}$} & $\mathrm{D}_{80}{ }^{\circ} \mathrm{C}(\mathrm{Sec})$ & 161.1 & 554.2 \\
& $\mathrm{Z}\left({ }^{\circ} \mathrm{C}\right)$ & 13.1 & 23.52 \\
\multirow{2}{*}{$85^{\circ} \mathrm{C}$} & $\mathrm{D}_{85}{ }^{\circ} \mathrm{C}(\mathrm{Sec})$ & 142.5 & 528.6 \\
& $\mathrm{Z}\left({ }^{\circ} \mathrm{C}\right)$ & 12.9 & 23.14 \\
$90{ }^{\circ} \mathrm{C}$ & $\mathrm{D}_{90}{ }^{\circ} \mathrm{C}(\mathrm{Sec})$ & 135.8 & 502.2 \\
& $\mathrm{Z}\left({ }^{\circ} \mathrm{C}\right)$ & 12.65 & 22.75 \\
$955^{\circ} \mathrm{C}$ & $\mathrm{D}_{95}{ }^{\circ} \mathrm{C}(\mathrm{Sec})$ & 105.2 & 491.6 \\
\hline
\end{tabular}


Table.3 Constraints for optimization of thermal process parameters

\begin{tabular}{lcccc}
\hline Variables & Condition & Lower Limit & Upper Limit & Importance \\
\hline $\begin{array}{l}\text { Treatment time }(\mathrm{min}) \\
\text { Temperature }\left({ }^{\circ} \mathrm{C}\right)\end{array}$ & Minimize & 2.5 & 10 & 3 \\
\hline Responses & Condition & 80 & 95 & 4 \\
\hline $\begin{array}{l}\text { Relative activity of PPO } \\
(\%)\end{array}$ & Minimize & 2 & 75 & 4 \\
$\begin{array}{l}\text { Relative activity of POD } \\
(\%)\end{array}$ & Minimize & 2 & 64 & 4 \\
$\begin{array}{l}\text { Loss of ascorbic acid } \\
(\%)\end{array}$ & Minimize & 2.91 & 14.24 & 3 \\
$\begin{array}{l}\text { Total phenolic content } \\
\text { (mg of GAE/ L) }\end{array}$ & Maximize & 51 & 67.5 & 3 \\
$\begin{array}{l}\text { Antioxidant capacity } \\
(\mathrm{mg} \text { of GAEAC/L) } \\
\text { Turbidity }(\%)\end{array}$ & Maximize & 0.65 & 0.75 & 3 \\
\hline
\end{tabular}

Table.4 Predicted optimum values for thermal variable and responses

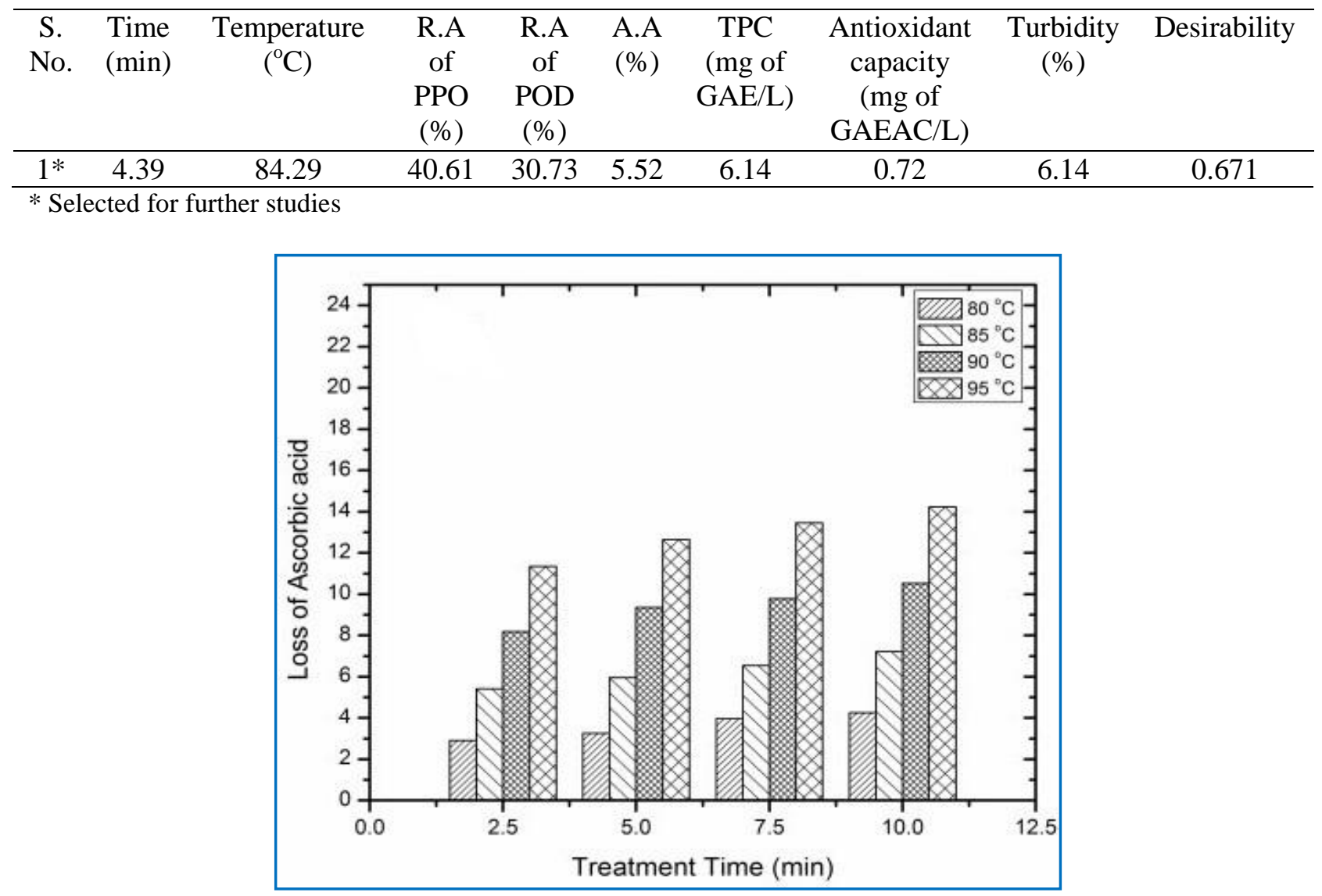

Fig.1 Effect of different thermal treatment conditions on ascorbic acid content of TCW 


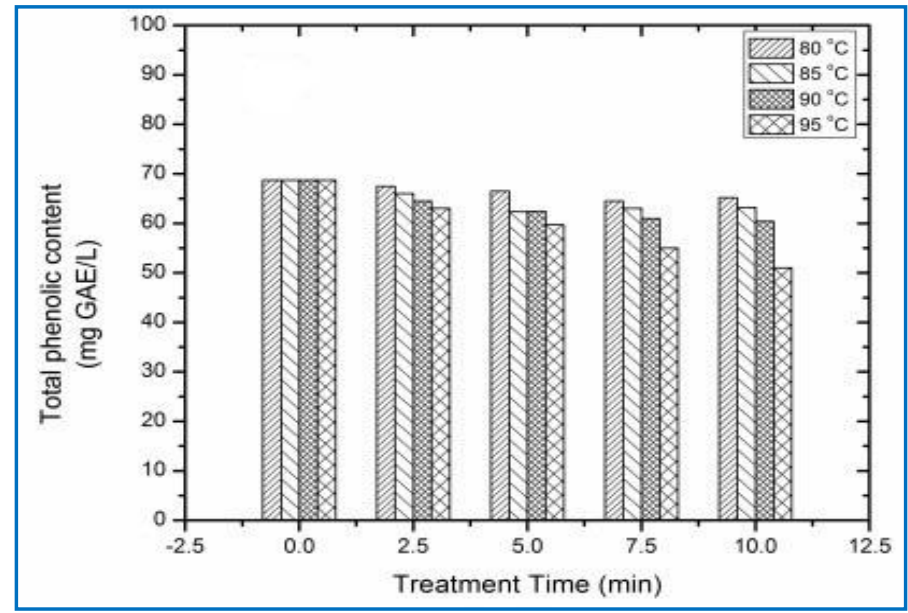

Fig. 2 Effect of different thermal treatment conditions on Total Phenolic content of TCW

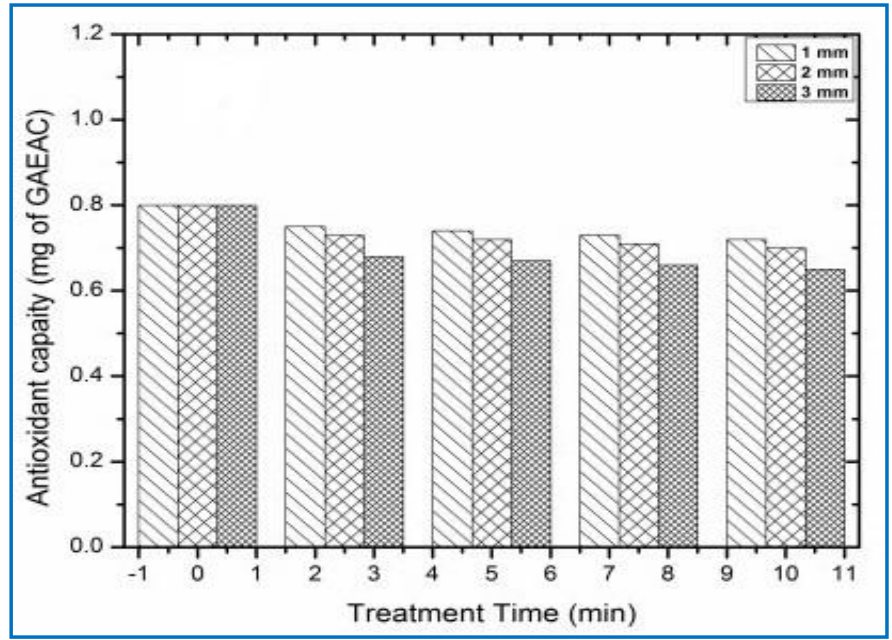

Fig.3 Effect of different thermal treatment conditions on total antioxidant activity of TCW

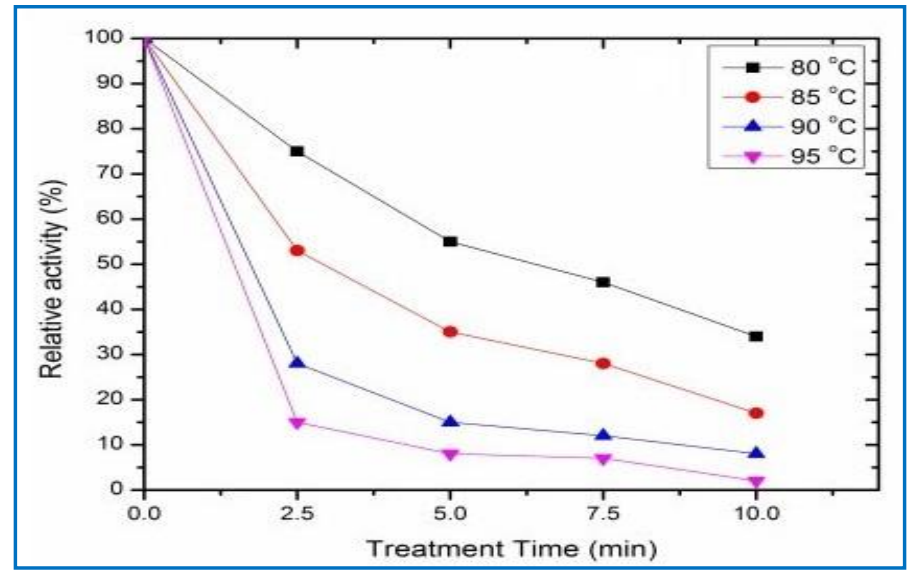

Fig.4 Effect of different thermal treatment conditions on relative activity of PPO of TCW 


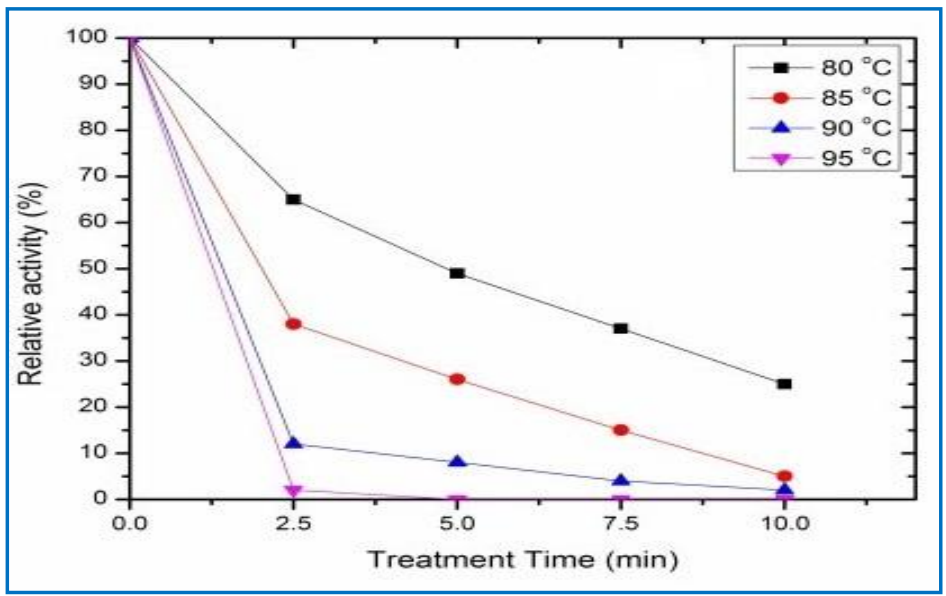

Fig.5 Effect of different thermal treatment conditions on relative activity of POD of TCW

\section{Effect on peroxidase (POD)}

The relative activity of POD of Thermally Processed TCW at different conditions was presented in figure 5. POD activity of TCW was found to be in the range of 0.06 to 0.078 $\left(\mathrm{U} \cdot \mathrm{mL}^{-1} \cdot \mathrm{min}^{-10} \mathrm{Brix}^{-1}\right)$. The obtained values of POD were found to be within the reported range in the literature (Tan et al., 2014). The results show that the relative activity of POD is lesser than the relative activity of PPO.

From ANOVA data it was showing that the thermal treatment conditions had significant $(\mathrm{p}<0.0001)$ effect on POD activity in TCW. The relative activity decreases with increasing time and temperature in thermal treatment. The complete inactivation of POD achieved after thermal processing at $95{ }^{\circ} \mathrm{C}$ for 5 minutes, though the experiment was continued up to $10 \mathrm{~min}$. because at this stage the PPO didn't inactive completely. It indicates that PPO is more heat resistant than POD in coconut water. The same trend was reported by Falguera et al., (2011) conducted on apple juice.

\section{Inactivation kinetics of PPO and POD}

A first order inactivation kinetic model was applied to describe the experimental results for POD and PPO in tender coconut water. Similar kinetic order has been applied on grapes (Fortea et al., 2009).

The inactivation kinetic parameters of PPO and POD of TCW were summarized in table 2. The temperature has shown significant effect on " $D$ " value and " $Z$ " value of TCW. With increasing treatment temperature, the value of " $D$ " has decreased.

Based on the inactivation kinetics parameters obtained in this study, PPO was found to be more heat resistant than POD. This finding is in agreement with the thermal curves of POD and PPO (Figs. 4 and 5), as well as findings reported by Campos et al., (1996), Matsui et al., (2008).

\section{Optimization of process parameters}

Optimization condition for thermal treated coconut was determined with the help of commercial software (Design Expert Version 7.0.0). The optimization of thermal treatment conditions was aimed to maximum inactivation of enzymes (viz. PPO and POD) which cause browning and off flavor, maximum retention of Ascorbic acid, Total phenolic content and Antioxidant activity. The detailed parameters with their importance 
and the obtained optimized condition are shown in tables 3 and 4 respectively.

Effect of thermal treatment of tender coconut water (Cocos nucifera) on Enzymes (PPO and POD) and nutritional properties (viz. Ascorbic acid, Total phenolic content and Antioxidant activity) were studied during this research work.

The process conditions for thermal treatment were temperature $\left(80,85,90,95{ }^{\circ} \mathrm{C}\right)$ and treatment time $(2.5,5,7.5,10 \mathrm{~min})$. The results obtained from this study showed that the thermal treatment conditions had significant effect on ascorbic acid, total phenols, antioxidant activity, PPO and POD. Further, inactivation kinetics parameters (viz. $\mathrm{D}$ value and $\mathrm{Z}$ value) were calculated for PPO and POD at different temperatures.

The complete inactivation of POD achieved after thermal processing at $95{ }^{\circ} \mathrm{C}$ for 5 minutes, though the experiment was continued up to $10 \mathrm{~min}$. because at this stage the PPO didn't inactive completely. These results evident that the PPO was more heat resistant than POD in thermal treatment. Further, the results were compared with enzyme activity and nutritional properties of tender coconut water after UV-C treatment.

From the results, the study was conclude that, although the thermal treatment was better processing option pertaining to enzyme inactivation, but ultraviolet treatment was found superior based on retention of nutritional attributes.

\section{Acknowledgment}

The authors express sincere thanks to IIT Kharagpur and ministry of MHRD, Govt. of India for providing financial support during the tenure of research work.

\section{References}

Augusto, P. E., Ibarz, R., Garvín, A., andIbarz, A. (2006). Peroxidase (POD) and polyphenol oxidase (PPO) photoinactivation in a coconut water model solution using ultraviolet (UV). Food Research International, 74, 151-159.

Augusto, P. E., Ibarz, R., Garvín, A., andIbarz, A. (2015). Peroxidase (POD) and polyphenol oxidase (PPO) photoinactivation in a coconut water model solution using ultraviolet (UV). Food Research International, 74, 151-159.

Bhat, R., Ameran, S. B., Voon, H. C., Karim, A. A., andTze, L. M. (2011). Quality attributes of starfruit (Averrhoa carambola L.) juice treated with ultraviolet radiation. Food Chemistry, 127(2), 641-644.

Bintsis, T., Litopoulou- Tzanetaki, E., and Robinson, R. K. (2000). Existing and potential applications of ultraviolet light in the food industry-a critical review. Journal of the Science of Food and Agriculture, 80(6), 637-645.

Bolton, J.R. Ultraviolet Applications Handbook, 1st Ed. 1999, Ayr, Ontario, Canada, Bolton Photosciences, Inc

Campbell-Falck, D., Thomas, T., Falck, T. M., Tutuo, N., and Clem, K. (2000). The intravenous use of coconut water. The American Journal of Emergency Medicine, 18(1), 108-111.

Campos, C. F., Souza, P. E. A., Coelho, J. V., and Glória, M. B. A. (1996). Chemical composition, enzyme activity and effect of enzyme inactivation on flavor quality of green coconut water. Journal of Food Processing and Preservation, 20(6), 487-500.

Canitez N., 2002. Pasteurization of Apple Cider with UV Irradiation. MS Thesis. The University of Maine

Chowdhury, M. M., Aziz, M. G., and Uddin, M. B. (2005). Development of shelf- 
stable ready-to-serve green coconut water. Biotechnology, 4(2), 121-125.

DebMandal, M., and Mandal, S. (2011). Coconut (Cocos nucifera L.: Arecaceae): in health promotion and disease prevention. Asian Pacific Journal of Tropical Medicine, 4(3), 241-247.

Falguera, V., Pagán, J., and Ibarz, A. (2011). Effect of UV irradiation on enzymatic activities and physicochemical properties of apple juices from different varieties. LWT-Food Science and Technology, 44(1), 115-119.

Gabriel, A. A., and Nakano, H. (2009).Inactivation of Salmonella, E. coli and Listeria monocytogenes in phosphate-buffered saline and apple juice by ultraviolet and heat treatments. Food Control,20, 443-446.

Goh, S. G., MohdAdzahan, N., Leong, C. M., Sew, C. C., and Sobhi, B. (2012). Effect of thermal and ultraviolet treatments on the stability of antioxidant compounds in single strength pineapple juice throughout refrigerated storage. Int. Food Res. J., 19(3), 1131-1136.

Goupy, P., Hugues, M., Boivin, P. and Amiot, M. J. (1999). Antioxidant composition and activity of barley (Hordeum vulgare) and malt extracts and of isolated phenolic compounds. Journal of the Science of Food and Agriculture, 79(12): 1625-1634.

Hahn, F. (2012). An on-line detector for efficiently sorting coconut water at four stages of maturity. Biosystems Engineering, 111(1), 49-56.

Jackson, J. C., Gordon, A., Wizzard, G., McCook, K., and Rolle, R. (2004). Changes in chemical composition of coconut (Cocos nucifera) water during maturation of the fruit. Journal of the Science of Food and Agriculture, 84(9), 1049-1052.
Kedare, S.B. and Singh, R.P. (2011). Genesis and development of DPPH method of antioxidant assay. Journal of Food Science and Technology, 48(4): 412422.

Krishnankutty S. 2005. Coconut Development Board (CDB), India.

Matsui, K. N., Gut, J. A. W., De Oliveira, P. V., andTadini, C. C. (2008). Inactivation kinetics of polyphenol oxidase and peroxidase in green coconut water by microwave processing. Journal of Food Engineering, 88(2), 169-176.

Miller, R.V., Jeffrey, W., Mitchell, D. and Elasri, M., 1999. Bacterial responses to ultraviolet light, American Society of Microbiology News65 (8):535-541.

Noci, F., Riener, J., Walkling-Ribeiro, M., Cronin, D. A., Morgan, D. J., andLyng, J. G. (2008). Ultraviolet irradiation and pulsed electric fields (PEF) in a hurdle strategy for the preservation of fresh apple juice. Journal of Food Engineering, 85(1), 141-146.

Ranganna S. (1991). Handbook of Analysis and Quality Control for Fruit and Vegetable Products. Tata McGraw-Hill Publishing Co. Ltd, New Delhi.3-19.

Sadasivam, S. and Manickam, A. (2011). In: Biochemical Methods. New Age International, New Delhi, pp. 53-54

Tan, T. C., Cheng, L. H., Bhat, R., Rusul, G., andEasa, A. M. (2014). Composition, physicochemical properties and thermal inactivation kinetics of polyphenol oxidase and peroxidase from coconut (Cocos nucifera L) water obtained from immature, mature and overly-mature coconut. Food Chemistry, 142, 121-128.

Tan, T. C., Cheng, L. H., Bhat, R., Rusul, G., andEasa, A. M. (2015). Effectiveness of ascorbic acid and sodium metabisulfite as anti-browning agent and antioxidant on green coconut water (Cocos nucifera L) subjected to elevated 
thermal processing. International Food Research Journal, 22(2), 631-637.

Walter, E. H. M., Nascimento, M. S., andKuaye, A. Y. (2009). Efficacy of sodium hypochlorite and peracetic acid in sanitizing green coconuts. Letters in Applied Microbiology, 49(3), 366-371.

Wijngaard, H. H. and Brunton, N. (2010). The optimization of solid-liquid extraction of antioxidants from apple pomace by response surface methodology. Journal of Food Engineering, 96(1): 134-140.

Yong, J. W., Ge, L., Ng, Y. F., and Tan, S. N. (2009). The chemical composition and biological properties of coconut (Cocos nucifera L.) Water Molecules, 14(12), 5144-5164.

\section{How to cite this article:}

Shivashankar Sanganamoni, S. Mallesh, K. Vandana and Srinivasa Rao, P. 2017. Thermal Treatment of Tender Coconut Water - Enzyme Inactivation and Biochemical Characterization. Int.J.Curr.Microbiol.App.Sci. 6(5): 2919-2931. doi: https://doi.org/10.20546/ijcmas.2017.605.331 